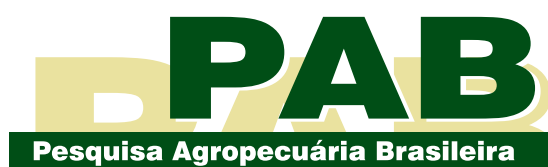

ISSN 1678-3921

Journal homepage: www.embrapa.br/pab

For manuscript submission and journal contents, access: www.scielo.br/pab

Douglas André Wurz ${ }^{(1 \otimes)}(\mathbb{D})$, José Luiz Marcon Filho(2) (D),

Alberto Fontanella Brighenti( ${ }^{(3)}$ (iD, Ricardo Allebrandt( ${ }^{(4)}$ (iD,

Betina Pereira de $\mathrm{Bem}^{(5)}$ (iD) and Leo Rufato(6) (iD

(1) Instituto Federal de Santa Catarina, Campus Canoinhas, Avenida Expedicionários, $\mathrm{Km} 7$, o 2.150, Campo da Água Verde CEP 89466-312 Canoinhas, SC, Brazil. E-mail: douglas.wurz@ifsc.edu.br

(2) Vinícola Legado, Rodovia Engenheiro Raul Azevedo de Macedo, ㄲo 5.800, CEP 83648-000 Campo Largo, PR, Brazil. E-mail: marconfilho_jl@yahoo.com.br

(3) Universidade Federal de Santa Catarina, Centro de Ciências Agrárias, Departamento de Fitotecnia, Rodovia Admar Gonzaga, no 1.346, Itacorubi, CEP 88040-900 Florianópolis, SC, Brazil.

E-mail: alberto.brighenti@ufsc.br

(4) Centro Universitário Dinâmica das Cataratas, Rua Castelo Branco, № 440, Centro, CEP 85852-010 Foz do Iguaçu, PR, Brazil. E-mail: ricardo.ufsc@gmail.com

(5) Instituto Federal de Santa Catarina, Campus Urupema, Estrada Senadinho, s/no $=$, CEP 88625-000 Urupema, SC, Brazil. E-mail: betadebem@yahoo.com.br

(6) Universidade do Estado de Santa Catarina, Centro de Ciências Agroveterinárias, Avenida Luis de Camões, no 2.090, Conta Dinheiro, CEP 88520-000 Lages, SC, Brazil. E-mail: leorufato@udesc.br

$凶$ Corresponding author

Received

April 24, 2020

Accepted

September 11, 2020

How to cite

WURZ, D.A.; MARCON FILHO, J.L.;

BRIGHENTI, A.F.; ALLEBRANDT, R.; BEM,

B.P. de; RUFATO, L. Phenolic composition of wine from 'Cabernet Sauvignon' grapes subjected to leaf removal in different timing, in Southern Brazil. Pesquisa Agropecuária Brasileira, v.55, e01919, 2020. DOI: https://doi. org/10.1590/S1678-3921.pab2020.v55.01919.
Pomology/ Original Article

\section{Phenolic composition of wine from 'Cabernet Sauvignon' grapes subjected to leaf removal at different timing in Southern Brazil}

\begin{abstract}
The objective of this work was to evaluate the phenolic composition of wine from 'Cabernet Sauvignon' (Vitis vinifera) grapes subjected to leaf removal management at different timing, in a high-altitude region. The experiment was carried out in the 2015 and 2016 vintages, in a vineyard located in the municipality of São Joaquim, in the state of Santa Catarina, Brazil. The treatments consisted of different periods of leaf removal in the clusters, at five phenological stages - full bloom, buckshot berries, pea-sized berries, veraison, and 15 days after veraison -, and of a control without leaf removal. At harvest, $50 \mathrm{~kg}$ of each treatment were collected for winemaking. The contents of gallic acid, catechin, p-coumaric acid, vanillic acid, resveratrol, quercetin, rutin, and kaempferol were evaluated. The results showed the importance of leaf removal before veraison, to obtain wine with a higher concentration of phenolic compounds, which favors wine quality. The leaf removal management promotes the increase of gallic acid, vanillic acid, p-coumaric acid, resveratrol, quercetin, and kaempferol in wine. The early leaf removal before veraison results in increases in vanillic acid, p-coumaric acid, resveratrol, quercetin, and kaempferol. The wine made from grapes not subjected to leaf removal shows higher values of catechin and rutin.
\end{abstract}

Index terms: Vitis vinifera, enology, gallic acid, phenological stage, resveratrol.

\section{Composição fenólica do vinho de uvas 'Cabernet Sauvignon' submetidas a diferentes épocas de desfolha na região Sul do Brasil}

Resumo - O objetivo deste trabalho foi avaliar a composição fenólica de vinho elaborado com uvas 'Cabernet Sauvignon' (Vitis vinifera) submetidas ao manejo de desfolha em várias épocas, em região de elevada altitude. $\mathrm{O}$ experimento foi conduzido nas safras de 2015 e 2016, em um vinhedo localizado no munícipio de São Joaquim, no estado de Santa Catarina, Brasil. Os tratamentos consistiram de diferentes épocas de desfolhas na região dos cachos, em cinco estádios fenológicos - plena florada, baga-chumbinho, baga-ervilha, mudança de cor das bagas (véraison) e 15 dias após o véraison -, e de um controle sem desfolha. Na fase da colheita, $50 \mathrm{~kg}$ de uvas de cada tratamento foram colhidos para a elaboração do vinho. Avaliaram-se as concentrações de ácido gálico, catequina, ácido p-cumárico, ácido vanílico, resveratrol, quercetina, rutina e campferol. Os resultados evidenciaram a importância do manejo precoce da desfolha antes do estágio de véraison, para a obtenção de vinho com maior conteúdo de compostos fenólicos, benéficos à qualidade do vinho. O manejo da desfolha promove o aumento de ácido gálico, ácido vanílico, ácido p-coumárico, resveratrol, quercetina e campferol no vinho. A desfolha precoce antes do estágio de véraison resulta em aumento de ácido vanílico, ácido p-coumárico, resveratrol, quercetina e campferol. $\mathrm{O}$ vinho elaborado com uvas não submetidas ao manejo da desfolha apresenta valores superiores de catequina e rutina.

Termos para indexação: Vitis vinifera, enologia, ácido gálico, estágio fenológico, resveratrol. 


\section{Introduction}

The high-altitude region of Santa Catarina state (SC) exhibits vineyards cultivated in lands elevated from 900 up to $1,400 \mathrm{~m}$ altitude, where grape phenological cycle is longer in comparison to other Brazilian wine producing regions (Brighenti et al., 2013). Wine produced in Santa Catarina have high-color quality or and aroma capable of differentiating them from wine made in other regions (Marcon Filho et al., 2015).

The 'Cabernet Sauvignon' (Vitis vinifera) has the largest acreage in the high-altitude regions of Santa Catarina state. However, it is a long-cycle variety (214 days) that requires a high-thermal sum to complete its phenological phases, whose harvests occur from the second half of April, a time when temperatures start to drop in the region (Brighenti et al., 2013). Associated with this fact, this region shows conditions such as high levels of organic matter in the soil (Zalamena et al., 2013), high-water availability, the adoption of vigorous rootstocks, and the vertical shoot position (VSP) training system, which results in excessive vegetative growth requiring canopy adjustment to promote the vineyard balance (Borghezan et al., 2011; Würz et al., 2017b). This combination of factors leads to the risk of harvesting 'Cabernet Sauvignon' grapes with inadequate maturation parameters, such as highacidity content, aggressive tannins, and excess of herbaceous aromas (Würz et al., 2017b).

Therefore, it is necessary to apply management practices to promote the vine production such as the vegetative balance, to allow of grape harvesting with the appropriate maturity levels, and to produce quality wine. Leaf removal stands out among the canopy management practices, and it is a cultural practice carried out in the cluster zones during the vegetative period, in order to modify grape quality (Poni et al., 2006).

Increasing fruit exposure to sunlight through leaf removal benefits the concentration of anthocyanins in grapes, particularly in colder regions, where excessive temperature of berries is not a problem (Lemut et al., 2013; Wurz et al., 2017a). It also results in a reduction of bunch-rot incidence, such as Botrytis cinerea (Molitor et al., 2011; Würz et al., 2020), and in better quality of berries during harvest (Poni, 2006; Würz et al., 2017b, 2018). Clusters exposed to sunlight by leaf removal generally have berries with higher levels of sugars, anthocyanins, and phenolic compounds than berries in shaded fruit (Poni et al., 2006, Diago et al., 2012, Würz et al., 2017b).

Several scientific studies carried out in high-altitude regions in the South of Brazil confirm that leaf removal has been an important tool for canopy management, which may reduce cluster compactness, reduce the occurrence of bunch rot, and improve the chemical composition of berries (Wurz et al., 2017a, 2017b, 2018, 2020). However, there is a lack of information about the effect of leaf removal on the phenolic compositions of wine.

Polyphenols play an important role in the sensory characteristics of wine, such as color, astringency, and bitterness, since they play a major role in the wine quality (Conde et al., 2007). The wine phenolic composition is currently under special research interest because of its associations with human healthpromoting effects, according to Lemut et al. (2013).

The objective of this work was to evaluate the wine phenolic composition of 'Cabernet Sauvignon' grapes, according to the time of leaf removal management, in the high-altitude region of Santa Catarina state, Southern Brazil.

\section{Materials and Methods}

The experiment was carried out in the vintages of 2015 and 2016, in a commercial vineyard $\left(28^{\circ} 17^{\prime} 39^{\prime \prime S}\right.$, $49^{\circ} 55^{\prime} 56^{\prime \prime} \mathrm{W}$, at $1,230 \mathrm{~m}$ altitude) located in the municipality of São Joaquim, in the state of Santa Catarina, Brazil. The experimental design was carried out in randomized complete blocks, with four blocks, and five plants per block.

The region's climate is classified as Köppen-Geiger classification, and displays 1,714 heliothermic index, $1,621 \mathrm{~mm}$ average annual rainfall, and $80 \%$ relative humidity (Tonietto \& Carbonneau, 2004). The soils of the region are classified as Cambissolo Húmico (Inceptisol), Neossolo Litólico (Entisol), and Nitossolo Háplico (Ultisol), developed from riodacite and basalt rocks (Santos et al., 2018).

A vineyard of 'Cabernet Sauvignon' grafted on 'Paulsen 1103' planted in 2004 was evaluated. Plants were spaced at $3.0 \times 1.5 \mathrm{~m}$, in rows arranged in the $\mathrm{N}-\mathrm{S}$ direction, trained in vertical shoot-position trellis (VSP), pruned in double spur cordon, at $1.2 \mathrm{~m}$ high above the ground, and covered with anti-hail net. 
The treatments in the vineyard consisted of leaf removal between November and January, in the 2015 and 2016 vintages, exposing the cluster zones in five different phenological stages - full bloom, buckshot berries, pea-sized berries, veraison, 15 days after veraison -, and a control without leaf removal. Leaf removal was performed manually by removing three basal leaves, including the opposite leaf to the cluster, exposing it completely.

The harvest date was determined according to the winery standards, on April 1, 2015 and March 17, 2016, when $50 \mathrm{~kg}$ of each treatment were harvested for winemaking. The microvinifications were carried out at the Enology Laboratory of Universidade Estadual de Santa Catarina, in Lages, SC, Brazil, following the protocol adapted from Pszczolkowski \& Lecco (2011).

The wine phenolic compounds were quantified in a high-performance liquid chromatography (HPLC), according to Cadahía et al. (2009), and adapted by Ferreira-Lima et al. (2013). A solution containing a mixture of all standards was prepared in a synthetic wine system. Synthetic wine $\left(5 \mathrm{~g} \mathrm{~L}^{-1}\right.$ tartaric acid, $12 \% \mathrm{v} \mathrm{v}^{-1}$ ethanol, and $\mathrm{pH} 3.2$ ) was used to avoid interference in the chromatographic separation and detection response. The calibration solutions were also prepared in synthetic wine by diluting the stock solution containing the mixture of the standards. All solutions were previously filtered through a $0.45 \mu \mathrm{m}$ pore membrane (PES-Kasvi membrane, São José dos Pinhais, PR, Brazil).

Approximately $2 \mathrm{~mL}$ of sample (wine or calibration solution) were filtered on a $0.45 \mu \mathrm{m}$ membrane with a syringe, and placed in the vial for direct injection into the high-performance liquid chromatography system. The reagents used in the analysis, such as acetonitrile ( $\geq 99.9 \%$, LabMaster, Pinhais, PR, Brazil), acetic acid ( $\geq 99.7 \%$, Sigma-Aldrich, Darmstadt, Germany), and methanol ( $\geq 99.8 \%$, LabMaster, Pinhais, PR, Brazil) were of chromatographic grade. Tartaric acid L (+) ( $\geq 99 \%$, Sigma-Aldrich) and ethanol $(\geq 99.8 \%$, SigmaAldrich) were of analytical grade. Water used for the analyzes was obtained through the Milli-Q purification system, Simplicity UV System (Millipore, MA, USA). The standards anhydrous gallic acid $(\geq 98 \%),(+)$ catechin ( $\geq 98 \%$ ), p-coumaric acid ( $\geq 98 \%$ ), vanillic acid $(\geq 97 \%$ ), resveratrol ( $\geq 95 \%$ ), quercetin ( $\geq 95 \%$ ), rutin ( $\geq 94 \%)$, and kaempferol $(\geq 97 \%)$ were obtained from Sigma-Aldrich.
Chromatographic analyses were performed using a high-performance liquid chromatography equipment (Shimadzu, Kyoto, Japan). The column was C18 (5 $\mu \mathrm{m}$, $250 \mathrm{~mm} \times 4.6 \mathrm{~mm}$, Restek). For each sample, a duplicate reading was performed, and when a variation $>10 \%$ was detected, a third reading was performed. Phenolic compounds were read at $280 \mathrm{~nm}$.

All solvents used as a mobile phase were previously filtered through a $0.45 \mu \mathrm{m}$ pore membrane. The calibration ranges and equations for determining the phenolic compounds are described (Table 1). All compounds $\left(\mathrm{mg} \mathrm{L}^{-1}\right)$ were determined by calibration curves with an external standard.

For the microvinifications, a completely randomized block design was carried out with four replicates. The variables were subjected to the analysis of variance, and when treatment effects were detected, the ScottKnott's test was performed, at 5\% probability.

\section{Results and Discussion}

The leaf removal management of 'Cabernet Sauvignon' affected the wine phenolic composition (Table 2). As to gallic acid, a similar behavior was observed depending on the time of leaf removal in both vintages. The lowest value of gallic acid was observed in wine made from grapes not subjected to leaf removal, with $16.5 \mathrm{mg} \mathrm{L}^{-1}$ and $16.9 \mathrm{mg} \mathrm{L}^{-1}$, in 2015 and 2016 vintages, respectively. For the other

Table 1. Quantification of phenolic compounds of wine from 'Cabernet Sauvignon' (Vitis vinifera) grapes subjected to different timing of leaf removal ${ }^{(1)}$ in 2015 and 2016 vintages in the municipality of São Joaquim, in the state of Santa Catarina, Brazil.

\begin{tabular}{lcccc}
\hline $\begin{array}{l}\text { Phenolic } \\
\text { compound }\end{array}$ & $\begin{array}{c}\text { Calibration } \\
\text { range } \\
\left(\mathrm{mg} \mathrm{L}^{-1}\right)\end{array}$ & $\begin{array}{c}\text { Linear } \\
\text { equation } \\
(\mathrm{y}=\mathrm{ax})\end{array}$ & $\mathrm{R}^{2}$ & $\begin{array}{c}\text { Quantification } \\
\text { threshold } \\
\left(\mathrm{mg} \mathrm{L}^{-1}\right)\end{array}$ \\
\hline Gallic acid & $0.8-78.1$ & $\mathrm{y}=62155 \mathrm{x}$ & 0.997 & 0.006 \\
Catechin & $0.4-158.8$ & $\mathrm{y}=17546 \mathrm{x}$ & 0.999 & 0.072 \\
Vanillic acid & $0.4-39.8$ & $\mathrm{y}=41400 \mathrm{x}$ & 0.998 & 0.026 \\
p-coumaric acid & $0.3-29.4$ & $\mathrm{y}=116481 \mathrm{x}$ & 0.996 & 0.009 \\
Rutin & $0.3-29.9$ & $\mathrm{y}=21032 \mathrm{x}$ & 0.996 & 0.033 \\
Resveratrol & $0.2-18.8$ & $\mathrm{y}=83839 \mathrm{x}$ & 0.994 & 0.013 \\
Quercetin & $0.6-58.9$ & $\mathrm{y}=33919 \mathrm{x}$ & 0.998 & 0.031 \\
Kaempferol & $0.1-13.4$ & $\mathrm{y}=40635 \mathrm{x}$ & 0.997 & 0.029 \\
\hline
\end{tabular}

(1) Leaf removal performed in five phenological stages - full bloom, buckshot berries, pea-sized berries, veraison, an at 15 days after veraison-, and a control without leaf removal. $\mathrm{R}^{2}$, coefficient of determination. 
treatments, which were subjected to leaf removal, gallic acid showed average values higher than $30 \mathrm{mg} \mathrm{L}^{-1}$ and $20 \mathrm{mg} \mathrm{L}^{-1}$, in 2015 and 2016 vintages, respectively, indicating that regardless of the leaf removal timing, there was an increase of the gallic acid content in 'Cabernet Sauvignon' wine.

The main hydroxybenzoic acid present in red wine is gallic acid, formed mainly by the hydrolysis of gallate flavonoids (Cartoni et al., 1991). Gallic acid is described as one of the most important phenolic compounds because it is a precursor to all hydrolysable tannins. It is important to note that leaf removal resulted in higher values of gallic acid, especially in comparison to studies made by other authors like Burin et al. (2011) and Simon (2014), who found 23.3 and $24.5 \mathrm{mg} \mathrm{L}^{-1}$ of gallic acid, respectively, in 'Cabernet Sauvignon' wine cultivated in São Joaquim, SC, Brazil.

In the 2015 vintage, the highest-catechin values were observed in wine made with grapes not subjected to leaf removal (Table 2), while in 2016, the highestcatechin values were observed in wine from grapes not subjected to leaf removal, and in grapes subjected to leaf removal 15 days after the veraison. The early leaf removal seems to reduce the catechin content in 'Cabernet Sauvignon' wine. In a previous study on the white cultivar 'Sauvignon Blanc' cultivated in a highaltitude region of Southern Brazil, higher-catechin values were observed in wine made with grapes not subjected to the leaf removal management (Wurz et al., 2017a).

Flavan-3-ols - mainly represented by catechin and epicatechin - are important compounds, as they give astringency to wine (Downey et al., 2003). Bitterness and astringency are associated with high levels of flavan-3-ols (Chapman et al., 2004).

The content of vanillic acid was influenced by the timing of leaf removal (Table 2). When leaf removal was performed in the stages full bloom, veraison, and at 15 days after veraison, lower values of vanillic acid were observed; however, when leaf removal was carried out in the phenological stages buckshot berries and pea-sized berries, an increase of this phenolic compound was verified.

A different behavior was observed in the two evaluated vintages, in relation to p-coumaric acid (Table 2). However, lower values of p-coumaric acid were observed in wine made with grapes not subjected to leaf removal, whereas higher values of $p$-coumaric acid were observed during the leaf removal at the stage of pea-sized berries, in both evaluated vintages. This group of compounds is important in the wine composition, mainly due to their ability to react with anthocyanins, consequently stabilizing the wine color (Gris et al., 2007). In the present work, the values of p-coumaric acid are higher than those reported by Burin et al. (2011), who reported 1.69 and $0.47 \mathrm{mg} \mathrm{L}^{-1}$ p-coumaric acid, which suggests that the leaf removal management allows of a higher accumulation of p-coumaric acid in 'Cabernet Sauvignon' wine.

'Cabernet Sauvignon' wine elaborated from grapes subjected to leaf removal resulted in lower-rutin contents than wine made with grapes not subjected to leaf removal, in both vintages (Table 3). The timing of leaf removal did not affect the rutin content. In a previous work, Wurz et al. (2017a) found higher-rutin values in 'Sauvignon Blanc' wine elaborated with grapes not subjected to leaf removal management.

Table 2. Effect of leaf removal timing on the phenolic composition (gallic acid, catechin, vanillic acid, and p-coumaric acid) of wine from 'Cabernet Sauvignon' (Vitis vinifera) grapes cultivated in a high-altitude region of Santa Catarina state, Brazil, in 2015 and 2016 vintages $^{(1)}$.

\begin{tabular}{|c|c|c|c|c|c|c|c|c|}
\hline \multirow[t]{2}{*}{ Leaf removal timing } & \multicolumn{2}{|c|}{ Gallic acid (mg L-1) } & \multicolumn{2}{|c|}{ Catechin $\left(\mathrm{mg} \mathrm{L}^{-1}\right)$} & \multicolumn{2}{|c|}{ Vanillic acid $\left(\mathrm{mg} \mathrm{L}^{-1}\right)$} & \multicolumn{2}{|c|}{ p-coumaric acid $\left(\mathrm{mg} \mathrm{L}^{-1}\right)$} \\
\hline & 2015 & 2016 & 2015 & 2016 & 2015 & 2016 & 2015 & 2016 \\
\hline Full bloom & $32.4 \mathrm{a}$ & $26.8 \mathrm{a}$ & $23.2 b$ & $21.2 b$ & $6.2 b$ & $6.6 b$ & $6.3 b$ & $4.1 b$ \\
\hline Buckshot berries & $36.6 \mathrm{a}$ & $23.2 \mathrm{a}$ & $17.2 \mathrm{c}$ & $23.2 b$ & $8.3 \mathrm{a}$ & $6.8 \mathrm{~b}$ & $6.5 b$ & $5.9 \mathrm{a}$ \\
\hline Pea-sized berries & $32.4 \mathrm{a}$ & $23.5 \mathrm{a}$ & $17.3 \mathrm{c}$ & $25.0 \mathrm{~b}$ & $6.8 \mathrm{a}$ & $9.9 \mathrm{a}$ & $7.2 \mathrm{a}$ & $6.4 \mathrm{a}$ \\
\hline Veraison & $34.5 \mathrm{a}$ & $23.6 \mathrm{a}$ & $17.2 \mathrm{c}$ & $26.3 b$ & $7.6 \mathrm{a}$ & $5.5 \mathrm{c}$ & $6.6 b$ & $4.5 b$ \\
\hline 15 days after veraison & $37.3 \mathrm{a}$ & $24.6 \mathrm{a}$ & $28.2 \mathrm{~b}$ & $33.8 \mathrm{a}$ & $7.1 \mathrm{a}$ & $5.2 \mathrm{c}$ & $6.1 \mathrm{~b}$ & $6.1 \mathrm{a}$ \\
\hline Control $^{(2)}$ & $16.5 b$ & $16.9 \mathrm{~b}$ & $32.6 \mathrm{a}$ & $35.2 \mathrm{a}$ & $5.3 \mathrm{c}$ & $6.0 \mathrm{~b}$ & $3.9 \mathrm{c}$ & $4.0 \mathrm{~b}$ \\
\hline
\end{tabular}

${ }^{(1)}$ Means followed by equal letters, in the columns, do not differ by Scott-Knott's test, at 5\% probability. ${ }^{(2)}$ Control, without leaf removal. 
The stilbenes monomers cis and trans-resveratrol are phytoalexins, that is, they are components synthesized by the grapevine in response to a situation of stress, caused by the exposure to ultraviolet light (UV) and by climatic conditions. The effects of sunshine duration and UV-light exposure on resveratrol concentrations of red wine were investigated separately, and the observations showed an increase of resveratrol concentrations to a considerable extent (Threlfall et al., 1999).

The timing of leaf removal influenced the content of resveratrol in 'Cabernet Sauvignon' wine, in both vintages (Table 3). In 2015, wine from grapes subjected to leaf removal in full bloom, buckshot berries, peasized berries, and veraison showed higher resveratrol levels. However, in 2016, the highest resveratrol level was observed in wine from grapes subjected to leaf removal in full bloom, followed by leaf removal at the stage of buckshot berries, which suggests the effectiveness of early leaf removal to increase the resveratrol contents in 'Cabernet Sauvignon' wine.

Among the phenolic compounds found in wine, the group of stilbenes is one of the most important, from which resveratrol (3,5,4' trihydroxy stilbene) stands out as one of the most studied phytoalexin for its putative role on human health (Gris et al., 2010). The growing interest in resveratrol is the result, principally, of its claimed role in protecting against coronary heart disease. This potential effect could be attributed to the antioxidant potential of resveratrol, and to the inhibition of low-density lipoprotein oxidation (Frankel et al., 1993).

The content of quercetin in 'Cabernet Sauvignon' wine was influenced by the timing of leaf removal
(Table 3). In both vintages, the lowest values of quercetin were observed in wine made with grapes not subjected to leaf removal, and with grapes defoliated 15 days after veraison, indicating that early leaf removal resulted in the increase of quercetin in 'Cabernet Sauvignon' wine. The leaf removal performed in full bloom resulted in wine with the highest content of quercetin.

Flavanols are important compounds for wine quality, as they contribute to bitterness and color, stabilizing the anthocyanins (Puértolas et al., 2010). Among the evaluated flavanols, quercetin was the most abundant in the analyzed wine. It has been known that the expression of genes involved in the regulation of flavanol synthesis is stimulated by sunlight (Downey et al., 2003; Ristic et al., 2007), and that the flavonol content in sun-exposed grapes is normally increased (Ristic et al., 2007). In the grape ripening phase, the clusters that are more exposed to the sun may contain up to ten times more flavonol contents than shaded clusters, which is due to the concentration increases of quercetin, kaempferol, and myricetin 3-glycoside (Spayd et al., 2002). According to the results obtained in the present work, it is possible to affirm that the early leaf removal, which allowed of a better cluster exposure to the sun, can promote higher accumulation of flavanols in grapes and, consequently, in wine.

The leaf removal resulted in higher values of kaempferol (Table 3). In both vintages, the lowestkaempferol values (from $0.04 \mathrm{mg} \mathrm{L}^{-1}$ to $0.02 \mathrm{mg} \mathrm{L}^{-1}$ ) were observed in wine from grapes not subjected to leaf removal.

A quality red-wine grape should contain a large amount of phenolic compounds, and, in that sense, leaf

Table 3. Effect of leaf removal timing on the phenolic composition (rutin, resveratrol, quercetin, kaempferol) of wine from 'Cabernet Sauvignon' (Vitis vinifera) grapes cultivated in a high-altitude region of Santa Catarina state, Brazil, in 2015 and 2016 vintages $^{(1)}$.

\begin{tabular}{|c|c|c|c|c|c|c|c|c|}
\hline \multirow[t]{2}{*}{ Leaf removal timing } & \multicolumn{2}{|c|}{ Rutin (mg L-1) } & \multicolumn{2}{|c|}{ Resveratrol $\left(\mathrm{mg} \mathrm{L}^{-1}\right)$} & \multicolumn{2}{|c|}{ Quercetin $\left(\mathrm{mg} \mathrm{L}^{-1}\right)$} & \multicolumn{2}{|c|}{ Kaempferol $\left(\mathrm{mg} \mathrm{L}^{-1}\right)$} \\
\hline & 2015 & 2016 & 2015 & 2016 & 2015 & 2016 & 2015 & 2016 \\
\hline Full bloom & $7.4 \mathrm{~b}$ & $7.2 \mathrm{~b}$ & $2.6 \mathrm{a}$ & $3.8 \mathrm{a}$ & $4.6 \mathrm{a}$ & $1.6 \mathrm{a}$ & $0.07 \mathrm{~b}$ & $0.08 \mathrm{a}$ \\
\hline Buckshot berries & $7.4 \mathrm{~b}$ & $8.9 \mathrm{~b}$ & $2.4 \mathrm{a}$ & $2.3 \mathrm{~b}$ & $1.9 \mathrm{c}$ & $1.4 \mathrm{a}$ & $0.17 \mathrm{a}$ & $0.04 \mathrm{~b}$ \\
\hline Pea-sized berries & $7.3 b$ & $7.4 \mathrm{~b}$ & $2.7 \mathrm{a}$ & $1.4 \mathrm{c}$ & $2.8 \mathrm{~b}$ & $1.2 \mathrm{a}$ & $0.10 \mathrm{~b}$ & $0.09 \mathrm{a}$ \\
\hline Veraison & $7.4 \mathrm{~b}$ & $8.8 \mathrm{~b}$ & $2.5 \mathrm{a}$ & $1.5 \mathrm{c}$ & $2.2 \mathrm{c}$ & $0.8 \mathrm{~b}$ & $0.15 \mathrm{a}$ & $0.12 \mathrm{a}$ \\
\hline 15 days after veraison & $7.3 b$ & $7.0 \mathrm{~b}$ & $1.9 \mathrm{~b}$ & $1.2 \mathrm{c}$ & $1.3 \mathrm{~d}$ & $0.4 \mathrm{c}$ & $0.07 \mathrm{~b}$ & $0.04 \mathrm{~b}$ \\
\hline Control $^{(2)}$ & $13.2 \mathrm{a}$ & $10.1 \mathrm{a}$ & $1.8 \mathrm{~b}$ & $1.4 \mathrm{c}$ & $1.1 \mathrm{~d}$ & $0.4 \mathrm{c}$ & $0.04 \mathrm{c}$ & $0.02 \mathrm{c}$ \\
\hline
\end{tabular}

${ }^{(1)}$ Means followed by equal letters, in the columns, do not differ by Scott-Knott's test, at $5 \%$ probability. ${ }^{(2)}$ Control, without leaf removal. 
removal has been an important canopy management to improve both the quantity and quality of phenolic compounds in berries and, consequently, in wine (Moreno et al., 2015; Würz et al., 2017b). The timing of leaf removal is an important factor in the accumulation of these compounds, therefore, leaf removal management is recommended to be performed before the phenological stage of veraison.

\section{Conclusions}

1. The management of grapevine (Vitis vinifera) according to the time of leaf removal influences the content of phenolic compounds in 'Cabernet Sauvignon' wine, from grapevines cultivated in high-altitude regions of Santa Catarina state, Southern Brazil.

2. Early leaf removal carried out before the phenological stage of veraison results in an increase of vanillic acid, p-coumaric acid, resveratrol, quercetin, and kaempferol contents in 'Cabernet Sauvignon' wine, which favors the wine quality.

3. Wine elaborated from grapes not subjected to leaf removal show higher values of catechin and rutin.

\section{References}

BORGHEZAN, M.; GAVIOLI, O.; PIT, F.A.; SILVA, A.L. da. Comportamento vegetativo e produtivo da videira e composição da uva em São Joaquim, Santa Catarina. Pesquisa Agropecuária Brasileira, v.46, p.398-405, 2011. DOI: https://doi.org/10.1590/ S0100-204X201100040000.

BRIGHENTI, A.F.; BRIGHENTI, E.; BONIN, V.; RUFATO, L. Caracterização fenológica e exigência térmica de diferentes variedades de uvas viníferas em São Joaquim, Santa Catarina - Brasil. Ciência Rural, v.43, p.1162-1167, 2013. DOI: https://doi.org/10.1590/S0103-84782013005000082.

BURIN, V.M.; SILVA, A.L. da; MALINOVSKI, L.I.; ROSIER, J.P.; FALCÃO, L.D.; BORDIGNON-LUIZ, M.T. Characterization and multivariate classification of grapes and wines of two Cabernet Sauvignon clones. Pesquisa Agropecuária Brasileira, v.46, p.474-481, 2011. DOI: https://doi.org/10.1590/S0100204X2011000500004.

CADAHÍA, E.; SIMÓN, B.F. de; SANZ, M.; POVEDA, P.; COLIO, J. Chemical and chromatic characteristics of Tempranillo, Cabernet Sauvignon and Merlot wines from DO Navarra aged in Spanish and French oak barrels. Food Chemistry, v.115, p.639649, 2009. DOI: https://doi.org/10.1016/j.foodchem.2008.12.076.

CARTONI, G.P.; COCCIOLI, F.; PONTELLI, L.; QUATTRUCCI, E. Separation and identification of free phenolic acids in wines by high-performance liquid chromatography. Journal of Chromatography A, v.537, p.93-99, 1991. DOI: https://doi.org/10.1016/S0021-9673(01)88889-0.
CHAPMAN, D.M.; MATTHEWS, M.A.; GUINARD, J.-X. Sensory attributes of Cabernet Sauvignon wines made from vines with different crop yields. American Journal of Enology and Viticulture, v.55, p.325-334, 2004.

CONDE, C.; SILVA, P.; FONTES, N.; DIAS, A.C.P.; TAVARES, R.M.; SOUSA, M.J.; AGASSE, A.; DELROT, S.; GERÓS, H. Biochemical changes throughout grape berry development and fruit and wine quality. Food, v.1, p.1-22, 2007.

DIAGO, M.P.; AYESTARÁN, B.; GUADALUPE, Z.; GARRIDO, A.; TARDAGUILA, J. Phenolic composition of Tempranillo wines following early defoliation of the vines. Journal of the Science of Food and Agriculture, v.92, p.925-934, 2012. DOI: https://doi.org/10.1002/jsfa.4671.

DOWNEY, M.; HARVEY, J.S.; ROBINSON, S.P. Analysis of tannins in seeds of skins of Shiraz grapes throughout berry development. Australian Journal of Grape and Wine Research, v.9, p.15-27, 2003. DOI: https://doi.org/10.1111/j.1755-0238.2003. tb00228.x.

FERREIRA-LIMA, N.E.; BURIN, V.M.; BORDIGNON-LUIZ, M.T. Characterization of Goethe white wines: influence of different storage conditions on the wine evolution during bottle aging. European Food Research and Technology, v.237, p.509520, 2013. DOI: https://doi.org/10.1007/s00217-013-2019-5.

FRANKEL, E.N.; KANNER, J.; GERMAN, J.B.; PARKS, E.; KINSELLA, J.E. Inhibition of oxidation of human low-density lipoprotein by phenolic substances in red wine. Lancet, v.341, n.8843, p.454-457, 1993. DOI: https://doi.org/10.1016/01406736(93)90206-V.

GRIS, E.F.; BURIN, V.M.; BRIGHENTI, E.; VIEIRA, H.; BORDIGNON-LUIZ, M.T. Phenology and ripening of Vitis vinifera L. grape varieties in São Joaquim, southern Brazil: a new South American wine growing region. Ciencia e Investigación Agraria, v.37, p.61-75, 2010. DOI: https://doi.org/10.4067/S071816202010000200007.

GRIS, E.F.; FERREIRA, E.A.; FALCÃO, L.D.; BORDIGNONLUIZ, M.T. Caffeic acid copigmentation of anthocyanins from Cabernet Sauvignon grape extracts in model systems. Food Chemistry, v.100, p.1289-1296, 2007. DOI: https://doi.org/10.1016/j.foodchem.2005.10.014.

LEMUT, M.S.; TROST, K.; SIVILOTTI, P.; ARAPITSAS, P.; VRHOVSEK, U. Early versus late leaf removal strategies for Pinot Noir (Vitis vinifera L.): effect on colour-related phenolics in young wines following alcoholic fermentation. Journal of the Science of Food and Agriculture, v.93, p.3670-3681, 2013. DOI: https://doi.org/10.1002/jsfa.6193.

MARCON FILHO, J.L.; HIPÓLITO, J. de S.; MACEDO, T.A. de; KRETZSCHMAR, A.A.; RUFATO, L. Raleio de cachos sobre o potencial enológico da uva 'Cabernet Franc' em duas safras. Ciência Rural, v.45, p.2150-2156, 2015. DOI: https://doi.org/10.1590/0103-8478cr20140995.

MOLITOR, D.; BEHR, M.; FISCHER, S.; HOFFMANN, L.; EVERS, D. Timing of cluster-zone leaf removal and its impact on canopy morphology, cluster architecture and bunch rot susceptibility of grapes. Journal International des 
Sciences de la Vigne et du Vin, v.45, p.149-159, 2011. DOI: https://doi.org/10.20870/oeno-one.2011.45.3.1495.

MORENO, D.; VILANOVA M.; GAMERO, E.; INTRIGLIOLO, D.S.; TALAVERANO, M.I.; URIARTE, D.; VALDÉS, M.E. Effects of preflowering leaf removal on phenolic composition of Tempranillo in the semi-arid terroir of Western Spain. American Journal of Enology and Viticulture, v.66, p.204-2011, 2015. DOI: https://doi.org/10.5344/ajev.2014.14087.

PONI, S.; CASALINI, L.; BERNIZZONI, F.; CIVARDI, S.; INTRIERI, C. Effects of early defoliation on shoot photosynthesis, yield components, and grape composition. American Journal of Enology and Viticulture, v.57, p.397-407, 2006.

PSZCZÓlKOWSKI, P.; LECCO, C.C. de. Manual de vinificación: Guía práctica para la elaboración de vinos. Santiago: Universidade Católica do Chile, 2011. 113p.

PUÉRTOLAS, E.; SALDAÑA, G.; CONDÓN, S.; ÁLVAREZ, I.; RASO, J. Evolution of polyphenolic compounds in red wine from Cabernet Sauvignon grapes processed by pulsed electric fields during aging in bottle. Food Chemistry, v.119, p.1063-1070, 2010. DOI: https://doi.org/10.1016/j.foodchem.2009.08.018.

RISTIC, R.; DOWNEY, M.O.; ILAND, P.G.; BINDON, K.; FRANCIS, I.L.; HERDERICH, M.; ROBINSON, S.P. Exclusion of sunlight from Shiraz grapes alters wine colour, tannin and sensory properties. Australian Journal of Grape and Wine Research, v.13, p.53-65, 2007. DOI: https://doi.org/10.1111/j.1755-0238.2007. tb00235.x.

SANTOS, H.G. dos; JACOMINE, P.K.T.; ANJOS, L.H. dos; OLIVEIRA, V.Á. de; LUMBRERAS, J.F.; COELHO, M.R.; ALMEIDA, J.A. de; ARAÚJO FILHO, J.C. de; OLIVEIRA, J.B. de; CUNHA, T.J.F. Sistema brasileira de classificação do solos. 5.ed. rev. e ampl. Brasília: Embrapa, 2018. 356p.

SIMON, S. Comportamento viti-enológico das variedades Merlot e Cabernet Sauvignon (Vitis Vinifera L.) em diferentes altitudes no sul do Brasil. 2014. Dissertação (Mestrado) Universidade Federal de Santa Catarina, Florianópolis.

SPAYD, S.E.; TARARA, J.M.; MEE, D.L.; FERGUSON, J.C. Separation of Sunlight and Temperature Effects on the Composition of Vitis vinifera cv. Merlot Berries. American Journal of Enology and Viticulture, v.53, p.171-182, 2002.
THRELFALL, R.T.; MORRIS, J.R.; MAUROMOUSTAKOS, A. Effect of variety, ultraviolet light exposure, and enological methods on the trans-resveratrol level of wine. American Journal of Enology and Viticulture, v.50, p.57-64, 1999.

TONIETTO, J.; CARBONNEAU, A. A multicriteria climatic classification system for grape-growing regions worldwide. Agricultural and Forest Meteorology, v.124, p.81-97, 2004. DOI: https://doi.org/10.1016/j.agrformet.2003.06.001.

WÜRZ, D.A.; ALLEBRANDT, R.; MARCON FILHO, J.L.; BEM, B.P. de; BRIGHENTI, A.F.; RUFATO, L.; KRETZSCHMAR, A.A. Época de desfolha e sua influência no desempenho vitícola da uva 'Sauvignon Blanc' em região de elevada altitude. Revista de Ciências Agroveterinárias, v.17, p.91-99, 2018. DOI: https://doi.org/10.5965/223811711712018091.

WURZ, D.A.; BEM, B.P. de; ALLEBRANDT, R.; MARCON FILHO, J.L.; BRIGHENTI, A.F.; OUTEMANE, M.; RUFATO, L.; KRETZSCHMAR, A.A. Timing of leaf removal modifies chemical and phenolic composition of Sauvignon Blanc wine. BIO Web of Conferences, v.9, art.02027, 2017a. DOI: https://doi.org/10.1051/bioconf/20170902027.

WÜRZ, D.A.; BRIGHENTI, A.F.; MARCON FILHO, J.L.; ALLEBRANDT, R.; BEM, B.P. de; RUFATO, L.; KRETZSCHMAR, A.A. Agronomic performance of 'Cabernet Sauvignon' with leaf removal management in a high-altitude region of Southern Brazil. Pesquisa Agropecuária Brasileira, v.52, p.869-876, 2017b. DOI: https://doi.org/10.1590/s0100$204 \times 2017001000006$.

WÜRZ, D.A.; RUFATO, L.; BOGO, A.; ALLEBRANDT, R.; BEM, B.P. de; MARCON FILHO, J.L.; BRIGHENTI, A.F.; BONIN, B.F. Effects of leaf removal on grape cluster architecture and control of Botrytis bunch rot in Sauvignon Blanc grapevines in Southern Brazil. Crop Protection, v.131, art.105079, 2020. DOI: https://doi.org/10.1016/j.cropro.2020.105079.

ZALAMENA, J.; CASSOL, P.C.; BRUNETTO, G.; GROHSKOPF, M.A.; MAFRA, M.S.H. Estado nutricional, vigor e produção em videiras cultivadas com plantas de cobertura. Revista Brasileira de Fruticultura, v.35, p.1190-1200, 2013. DOI: https://doi.org/10.1590/S0100-29452013000400030. 